\title{
OPTIMAL LIFE-CYCLE INVESTMENT STRATEGY IN LITHUANIAN SECOND PENSION PILLAR
}

\author{
TEODORAS MEDAISKIS, TADAS GUDAITIS, JAROSLAV MEČKOVSKI
}

\begin{abstract}
:
The proposition to introduce life-cycle investment strategy as a default option in second pension pillar in Lithuania is currently being intensely discussed as a measure to solve the problems of the irrational behaviour of pension fund participants. The latest analysis has shown that the majority of participants have selected an inappropriate pension fund (investment strategy and investment risk) while evaluating the accumulation period that they have left till the retirement. Moreover, most of them are not active and do not change the pension fund during accumulation period. The life-cycle investment strategy allows participants to switch automatically and gradually from one asset allocation to another as they get closer to retirement. Therefore, such dynamic asset allocation must have a strong analytical foundation. The goal of the study is to evaluate the optimal life-cycle investment strategy in the Lithuanian second pension pillar. In order to achieve this goal, the authors prepared a quantitatively calibrated model that closely follows such works as Cocco et al. (2005), Bagliano et al. (2009) and Blake et al. (2008). The model takes into account the specifics of the Lithuanian market such as contribution rates, the investment performance of pension funds, and participant's labour income process. In this paper, the authors use the optimization problem, where participant's utility is maximized only by the selected investment strategy (without consumption). The results show that from the beginning of accumulation period (the age of 20) till the age of approximately 42 years it is most rational to invest a high proportion of participant's pension assets into equities. Then optimal asset allocation is gradually switching from equities to less risky assets (e.g. government bonds) as the retirement age (65) approaches, where only 19 per cent of assets are invested into equities. The paper consists of three main parts: literature review, the explanation of the model and calibrated parameters that were used to evaluate the optimal life-cycle investment strategy, and main simulation results, including benchmark and sensitivity analysis.
\end{abstract}

\section{Keywords:}

Pension funds, life-cycle investment, investment strategy.

JEL Classification: J32, D14, G11

\section{Authors:}

TEODORAS MEDAISKIS, Vilnius University, Lithuania, Email: teodoras.medaiskis@evaf.vu.It TADAS GUDAITIS, Vilnius University, Lithuania, Email: tadas.gudaitis@evaf.vu.It JAROSLAV MEČKOVSKI, Vilnius University, Lithuania, Email: jaroslav.meckovski@gmail.com

\section{Citation:}

TEODORAS MEDAISKIS, TADAS GUDAITIS, JAROSLAV MEČKOVSKI (2018). OPTIMAL LIFE-CYCLE INVESTMENT STRATEGY IN LITHUANIAN SECOND PENSION PILLAR. International Journal of Economic 
Sciences, Vol. VII(2), pp. 70-86., 10.20472/ES.2018.7.2.004

This research was funded by a grant (No. MIP-15204) from the Research Council of Lithuania. This research was performed in cooperation with Vilnius University. The authors would like to thank Andrius Škarnulis, PhD for his help and suggestions. 


\section{Introduction}

The fully funded second pillar pension was introduced in Lithuania from 1 January 2004 by reforming pension system, which previously was based only on pay-as-you-go principle.

The second pension pillar is based on the individual fully funded accounts of participants who are allowed to pay a part of their obligatory pension insurance contribution into their personal account, instead of paying the full contribution into the state social insurance fund (the first pension pillar). Due to this, the acquired first pillar old-age pension rights of the participants are proportionally reduced.

The second pillar is administrated by pension accumulation companies, which manage several pension funds with different investment strategies. Participation in the second pension pillar not like in many other countries with similar system - is completely voluntary in Lithuania. By the end of 2017 Q3, more than 1.27 million participants - 96 percent of those eligible for a full pension - are accumulating capital in second pillar pension funds. The main principles of the pension reform in Lithuania are similar to many other post-communist countries (Latvia, Estonia, Poland etc.), where pension systems were reformed earlier (see Égert, 2012; Volskis, 2012; Jankauskienè and Medaiskis, 2014).

Each pension accumulation company offers 3 to 6 pension funds with various investment strategies in Lithuania. Pension funds are divided into four groups according to their investment strategy. Most of the second pillar pension funds are "mixed": assets of these funds are invested into high investment risk asset classes (e.g. equities) and into less risky asset classes (e.g. government bonds). According to the data of the Bank of Lithuania (2016), second pension pillar funds are divided into the following four groups depending on share of investments into equities:

- conservative pension funds (assets under management (hereinafter, AUM) are not invested into equities);

- pension funds investing a small part into equities (up to 30 per cent of AUM are invested into equities);

- pension funds investing a medium part into equities (up to 70 per cent of AUM are invested into equities);

- pure equity pension funds (up to 100 per cent of AUM are invested into equities).

In 2008-2009 global financial crisis significantly affected second pension pillar. On the one hand, the accumulated capital lost value due to turbulence in financial markets, on the other hand, contributions to second pillar pension funds were decreased from $5.5 \%$ to $1.5 \%$ in 2009 due to fiscal deficit. Later, the government decided to change the participation level (rules), and in 2013 participants of second pillar pension funds had to choose their participation level (contributions level) by selecting one of the following options:

- to stop further participation in the second pillar.

- to increase participation in the second pillar (by paying additional 2 per cent contribution supplemented with a state contribution of 2 per cent of average country wage).

- $\quad$ to stay with previous participation level (see Maccioni and Gudaitis, 2014).

It is expected that a pension fund participant will be active and will change the pension fund strategy (risk) during the long-term pension accumulation period. However, our recent analysis (see Medaiskis et al., 2018) of the data of the State Social Insurance Fund Board (Sodra), has 
showed that the behaviour of participants is not as rational as it was expected. The majority of pension fund participants have selected an inappropriate pension fund (according on investment strategy and investment risk) while evaluating the accumulation period which they have left till retirement. The results show that young participants selected too conservative investment strategies, which means that in the beginning of their participation in the second pension pillar they do not take full advantage of higher returns in equity markets. Meanwhile, senior participants tend to opt for a larger investment risk before retirement by choosing pension funds that invest a larger part of AUM into equities. The analysis also shows that participants are inactive and do not change the investment strategy over the accumulation period. Even those participants who have changed the pension fund made irrational decisions and chose an inappropriate pension fund (according to investment strategy and risk) during various stages of the development of financial markets. In case of a peak in stock markets, participants choose to switch from a fund with a lower proportion of equities, to the fund with a higher proportion of equities. In case of a bottom in stock markets, participants acted vice versa.

Recently, in Lithuania it was debated whether the introduction of life-cycle investment strategies as the default option for the second pension pillar could be a solution to the problems described above (see Bank of Lithuania (2017)). This investment strategy lets participants to move gradually from one asset allocation to another as they get older. It means that young citizens in the beginning of the accumulation period will participate in the second pension pillar with a high proportion of equities in their portfolio and will gradually shift to more conservative asset allocation as the target date (retirement) approaches. Therefore, such dynamic asset allocation must have a strong analytical foundation.

The goal of the paper is to evaluate the optimal life-cycle investment strategy in Lithuanian second pension pillar using a realistically and quantitatively calibrated model. Authors aims to test a hypothesis, if life-cycle investment strategy would be rational choice for second pillar pension fund's participant.

The paper consists of three main parts. At the beginning, previous research on this topic is briefly described. Secondly, the model and calibrated parameters that were used to evaluate optimal life-cycle investment strategy are explained. Finally, the main simulation results, including benchmark case and sensitivity analysis, are presented.

\section{Literature review}

In scientific literature, the analysis of optimal investment strategy during a person's life-cycle has already been started in the late 1960s. Samuelson (1969) and Merton (1969) demonstrated that it is optimal to invest a constant proportion of a person's assets into equities during all his accumulation period. They argue that such investment strategy depends only on the person's risk aversion and equity risk premium, but not on his age or accumulated wealth. However, these authors made the unrealistic assumption that an individual's consumption is determined by his financial wealth, but not by future labour income.

Bodie et al. (1992) showed that labour and investment choices are intimately related. Thus a person simultaneously selects his optimal levels of current consumption, labour effort and investment portfolio at each period in the life-cycle. They also suggest that at any age, greater labour flexibility will include greater risk taking in the individual's financial investment.

Empirical studies (e.g. Bodie et al. (1992) and Viceira (2001)) have confirmed that it is optimal for persons to hold proportionally more equities in their portfolios and to shift their investments towards riskless assets as they approach retirement age. This popular financial advice is also 
supported by other studies. Cocco et al. (2005) solved a dynamic realistically calibrated lifecycle model of consumption and portfolio choice with borrowing constraints. In this study, nontradable labour income shocks are allowed to follow specific stochastic processes. These authors have found that a life-cycle investment strategy that reduces an individual's equity share in portfolio as he ages may be optimal depending on the shape of the labour income profile. Also, ignoring labour income generates large utility costs. However, after comparison with alternative strategies, the authors consider this popular financial advice to be quite imprecise. Moreover, it does not take risk aversion and the riskiness of labour income into account. Bagliano et al. (2009) have extended the model described above by introducing bonds as the second risky asset. This allowed them to obtain minor variations with respect to known results. Furthermore, Blake et al. (2008) investigated pension accumulation strategies under the assumption that an individual has an Epstein-Zin utility function that allows a separation between risk aversion and elasticity of intertemporal substitution. This analysis has also confirmed that an accumulation approach with a high weight in equity-type investments and a gradual switch into bond-type investments as retirement approaches is an optimal strategy. The authors have also found that the optimal contribution rate is not constant, and exhibits a Ushaped pattern during the accumulation period.

In scientific literature (e.g. Cocco et al. (2005), Bagliano et al. (2009), Blake et al. (2008)), the motive for reducing the share of equities in portfolio as a person approaches the retirement age is explained through the ratio of human capital (i.e. discounted expected future labour income) and financial wealth. This ratio changes over an individual's life-cycle in such a way that it increases in the early part of working life to reach a peak and then start to decline. Human capital can be considered as implicit riskless asset holdings, which lose weight as person ages, leading him to hold more riskless assets in his financial portfolio. Ibbotson et al. (2007) consider that the characteristics of human capital have a significant impact on optimal portfolio allocation. Thus it is necessary to determine the human capital risk and whether it is correlated with financial market risk.

Fachinger and Mader (2007) provide two arguments to support the advice to reduce the share of equities in portfolio as retirement approaches, regardless of the individual's risk preferences or a particular life situation. First argument is time diversification, which means that equity risk is decreased by long holding periods. Over a longer period of time, short-term equity market fluctuations are assumed to be less important. The second argument is the targeting for large liquidity needs in midlife. This means that when individuals save towards a specific goal, such as retirement, having higher equity exposure at the beginning of accumulation will lead to higher average returns. As the target date approaches, a person should decrease risk exposure to minimize the likelihood of missing their target.

Several studies performed a comparison of life-cycle and other investment strategies. Pfau (2010) compared life-cycle and fixed asset allocation strategies. The analysis confirms that persons with very reasonable amounts of risk aversion may prefer the life-cycle approach, despite the tendency for aggressive fixed allocation strategies to produce larger expected wealth. The results prove that the life-cycle strategy can be justified even in a framework that includes only financial wealth. Antolin et al. (2010) assessed the relative performance of different investment strategies for various pay-out phases. They found that life-cycle strategies that maintain a constant exposure to equities during most of the accumulation period, switching swiftly to bonds in the last decade before retirement, seem to produce better results and are easier to explain. 
According to Azoulay et al. (2016), life-cycle funds have gained favour with retirement plan participants in recent years because they offer robust portfolio growth in the beginning of accumulation and the preservation of accumulated wealth before retirement. Also there is no need for participants to keep a constant watch on their investment strategy.

Bagliano et al. (2017) extended the life-cycle model allowing for a small risk of long-term unemployment with permanent effects on labour income. Therefore, the effects of unemployment on life-cycle savings and portfolio choice were investigated.

\section{Methodology}

\subsection{The model}

In order to evaluate the optimal life-cycle investment strategy for the Lithuanian second pension pillar, the authors constructed the model that is closely related to such works as Cocco et al. (2005), Bagliano et al. (2009) and Blake et al. (2008). Due to specifics of participation in the Lithuanian second pension pillar, the authors introduced necessary modifications to the model, which was presented in these papers.

In this model, it is considered that a participant begins to accumulate in the second pension pillar at the age of 20 , works for 45 years, and retires at the age of 65 . The accumulation period is denoted $t$, then index $20+t$ indicates the participant's age (in the beginning of accumulation, $t$ is equal to 0 ). Authors make an assumption, that individual receive steady regular income during accumulation period. Additionally, unisex principle is used in the model. Therefore, such sociodemographic factors as genders' wage gap, duration of parental leave and different retirement age for genders are not included in the model. Before analysing a person's life-cycle investment strategy optimization problem, it is necessary to define his labour income process and investment opportunities.

The labour income process. Each year, participant $i$ receives an average monthly real labour income $\left(Y_{i, 20+t}\right)$, modelled as an index, with the base of value at age of 20 . Thus, each participant at the age of 20 receives an average monthly income equal to $1\left(Y_{i, 20}=1\right)$. The person's labour income process is represented in following equation:

$$
Y_{i, 20+t}=\frac{\exp \left(r_{I}+S_{20+t}+u_{i, 20+t}+n_{i, 20+t}\right)}{\exp \left(r_{I}+S_{20}\right)}
$$

Here $r_{I}$ is the long-term average real rate of income growth (reflecting productivity growth in the economy), $S_{20+t}$ is the career income profile, $u_{i, 20+t}$ is permanent shock to participant's $i$ labour income and $n_{i, 20+t}$ is a transitory shock to his labour income.

The career income profile $S_{20+t}$ denotes the deterministic trend component of permanent income, which depends on age. It is considered that this component is equal for all participants. In this model, career income profile is expressed as a logarithm of real labour income $I_{20+t}$, which is evaluated by econometric methods as a function of a person's age (see Figure 1 below). Formally, this variable is described in equation (2).

$$
S_{20+t} \equiv \log \left(I_{20+t}\right)=f(20+t)
$$

The labour income process is also exposed to permanent and transitory shocks, which are uncorrelated across participants. These two variables permit to include a specified degree of uncertainty to the labour income process. Transitory shock $n_{i, 20+t}$ is distributed as $N\left(0, \sigma_{n}^{2}\right)$ and 
uncorrelated with permanent shock $u_{i, 20+t}$. It is assumed that permanent shock follows a random walk process:

$$
u_{i, 20+t}=u_{i, 20+t-1}+\varepsilon_{i, 20+t}
$$

Where $\varepsilon_{i, 20+t}$ is distributed as $N\left(0, \sigma_{\varepsilon}^{2}\right)$ and uncorrelated with $n_{i, 20+t}$.

Investment opportunities. In this model, contributions and accumulated capital in a second pension pillar individual account can be invested in two types of assets: riskless and risky assets. The annual gross real return of riskless asset $R_{i, 20+t}^{f}$ (e.g. government bonds) is described in equation (4).

$$
R_{i, 20+t}^{f}=r+v_{i, 20+t}
$$

Where $r$ is mean (long-term) return of riskless asset and $v_{i, 20+t}$ are innovations to the return of riskless asset, which are distributed as $N\left(0, \sigma_{v}^{2}\right)$. Furthermore, the annual gross real return of risky asset $R_{i, 20+t}$ (e.g. equities) is given by:

$$
R_{i, 20+t}=r+\mu_{20+t}+\eta_{i, 20+t}
$$

Where $\mu_{20+t}$ is a mean risk premium on the risky asset and $\eta_{i, 20+t}$ are innovations to the return of risky asset, which are distributed as $N\left(0, \sigma_{\eta}^{2}\right)$. Moreover, correlation between innovations to risky asset return $\eta_{i, 20+t}$ and labour income shocks $\varepsilon_{i, 20+t}$ is allowed. This correlation coefficient will be written as $\rho$.

In each period, it is decided what share of a participant's portfolio will be invested into equities (risky assets). Let this parameter be denoted as $\alpha_{i, 20+t}$. The short sales of assets and borrowing in this model are not allowed, which implies that a proportion of assets invested into equities cannot be negative in each period $\left(0 \leq \alpha_{i, 20+t} \leq 1\right)$. Thus a person's $i$ portfolio return $R_{i, 20+t}^{p}$ at each period of accumulation $t$ can be written as:

$$
R_{i, 20+t}^{p}=\alpha_{i, 20+t} \cdot R_{i, 20+t}+\left(1-\alpha_{i, 20+t}\right) \cdot R_{i, 20+t}^{f}
$$

Moreover, the case, when the pension accumulation company does not continue to invest a person's pension assets after the beginning of his retirement, is considered.

The participant's optimization problem. A participant's accumulation process is described as follows: the participant $i$ starts the period $t$ with accumulated wealth in a second pension pillar individual account $W_{i, 20+t}$ and during the year he transacts 12 monthly contributions from his labour income $\left(12 \cdot c \cdot Y_{i, 20+t}\right)$ to this pillar. In the beginning of the period $t$, it is decided how to allocate his assets in the pension account between risky and riskless assets during this period. Thus the accumulated wealth in the beginning of period $t+1$ (or participant's age of $20+t+1$ ) will be equal to:

$$
W_{i, 20+t+1}=\left(W_{i, 20+t}+12 \cdot c \cdot Y_{i, 20+t}\right) \cdot\left(1+R_{i, 20+t}^{p}\right)
$$

Where $c$ denotes a constant monthly contribution rate to the second pension pillar. Also, it is assumed that a person's initial wealth (before the start of participation) $W_{i, 20}$ will be equal to 1 .

According to equations (6) and (7), the participant's accumulated wealth in the second pension pillar at the beginning of period $t+1$ depends on the selected investment strategy $\left(\alpha_{i, 20+t}\right)$ and investment returns on both types of assets from the previous period. The accumulated wealth in a person's pension account before the retirement (at the beginning of age 65) is described by equation (8). 


$$
W_{i, 65}=\left(W_{i, 64}+12 \cdot c \cdot Y_{i, 64}\right) \cdot\left(1+R_{i, 64}^{p}\right)
$$

In Lithuania, participants of the second pension pillar transfer contributions to their pension funds' individual accounts as a constant share of their labour income, which is determined by the government. They also receive state contributions to individual accounts if they make the decision to increase their participation level. Thus in each period participants are not allowed to change their contribution rate and, respectively, their consumption. By choosing to increase the contribution rate to the second pension pillar, participants would consume less in that period in order to accumulate more wealth in a pension account and consume more at the retirement.

In the analysed papers (Cocco et al. (2005), Bagliano et al. (2009) and Blake et al. (2008)), person's utility over his lifetime is maximized by choosing not only investment strategy, but also consumption. Due to the specifics of the Lithuanian market, which were mentioned above, the authors needed to find another approach of optimization. Since in Lithuania participants are not allowed to choose their individual contribution rate for each period, it is assumed that maximizing the utility from accumulated wealth right before retirement is the most important of accumulation for them. It is considered, that persons transfer their contributions to second pension pillar individual accounts during all accumulation process and expect, that their accumulated wealth before retirement will be the biggest as possible. It is important, because in the beginning of retirement accumulated wealth is transformed into riskless fixed annuity for rest of life.

Due to these reasons, participant's utility will be calculated from his accumulated wealth before retirement (when age is 65). In analysed papers, power utility function (CRRA) was used in utility calculations. In this case, where utility is measured only for one period, authors applied positive form of exponential utility function (CARA), which is also one of the most common utility functions (see Gerber and Pafumi (1991), Johnson (2007), Meyer (2007)). Thus in this model participant's $i$ utility from accumulated wealth before retirement $W_{i, 65}$ is represented in following equation:

$$
V_{i}\left(W_{i, 65}\right)=\frac{1}{(1+r)^{45}} \cdot p_{20,65} \cdot\left(1-e^{-\gamma W_{i, 65}}\right)
$$

Where $p_{20,65}$ denotes probability that person, aged 20, will survive till retirement at age $65, \gamma$ is constant absolute risk aversion parameter. It is assumed that in life-cycle pension fund same investment strategy will be applied to all participants of equal age. Due to this, optimal person's asset allocation in each period of accumulation $\left(\alpha_{20+t}\right)$ can be evaluated by maximizing the total utility of all participants of a pension fund. Formally, this can be represented in the following equation, where $N$ denotes total number of simulated participants:

$$
\max _{0 \leq \alpha_{20+t} \leq 1} \sum_{i=1}^{N} V_{i}\left(W_{i, 65}\right)
$$

In order to solve this problem, authors used L-BFGS-B method. It is a limited memory algorithm for solving large non-linear optimization problems subject to simple bounds on the variable (for more details, see Byrd et al. (1994) and Zhu et al. (1994)). All simulations and calculations have been carried out using "R" code (with package "optim"), prepared by authors.

\subsection{Parameter calibration}

For the model presented in the previous section, it is necessary to select realistic parameter values concerning a participant's labour income process during his working life, survival probability and investment preferences. It is also important to define parameters related to the 
returns of risky and riskless assets in Lithuania. This set of benchmark parameter values is expressed in real terms, thus inflation does not influence the main results of the model.

As it was mentioned above, a person begins to participate in the second pension pillar at the age of 20 and retires at the age of 65 . According to the data of European Commission, the probability of surviving from the age of 20 to the age of 65 for both genders in Lithuania is equal to $75.44 \%$. As regards preferences, the coefficient of constant absolute risk aversion $\gamma$ is set to 0.03 , which was used in one of the studies analysed by Babcock et al. (1993). Also it is considered that in the benchmark case a person is participating in the second pension pillar with an increased level of contributions. According to the legislation, after the $1^{\text {st }}$ of January 2014 new participants might start to accumulate in the second pension pillar only with this option. It means that a participant is paying not only $2 \%$ of his labour income to second pension pillar each month, but also a $2 \%$ additional contribution supplemented with a state contribution of $2 \%$ of average country wage. For the sake of simplicity, the authors considered that a participant's constant monthly contribution rate is equal to $6 \%$ of his monthly real labour income (i.e. $c=0.06$ ). Also, the annualised long-term real growth rate of labour income is assumed to be $r_{I}=0.01$.

A person's labour income process is calibrated using depersonalized data of all 1.2 million pension fund participants, which was provided by the State Social Insurance Fund Board (Sodra), for the period from 2004Q2 till 2016Q3. In order to prepare the data of a participant's income in real terms, the authors deflated it using the harmonised index of consumer prices (HICP). A participant's career income profile $S_{20+t}$ in Lithuania is estimated by closely following the methodology described by Fernandez-Villaverde and Krueger (2007) and Kolasa (2012). The logarithm of real monthly labour income is regressed on cohort and year dummy variables and second-order polynomial in age. All coefficients of this regression are statistically significant. As it can be seen from Figure 1, this estimated age dependent trend has the typical humpshaped profile. The error structure of a participant's labour income process is estimated using a variance decomposition method (see Cocco et al. (2005) and Carroll and Samwick (1997)). In the benchmark case, the standard deviations of the permanent and transitory shocks to income are set at $\sigma_{\varepsilon}=0.0885$ and $\sigma_{n}=0.0445$. Furthermore, according to the Bank of Lithuania (2013), the correlation $(\rho)$ between innovations to risky asset returns $\eta$ and labour income shocks $\varepsilon$ in Lithuania is equal to 0.35 .

Figure 1. Second pension pillar participant's career income profile

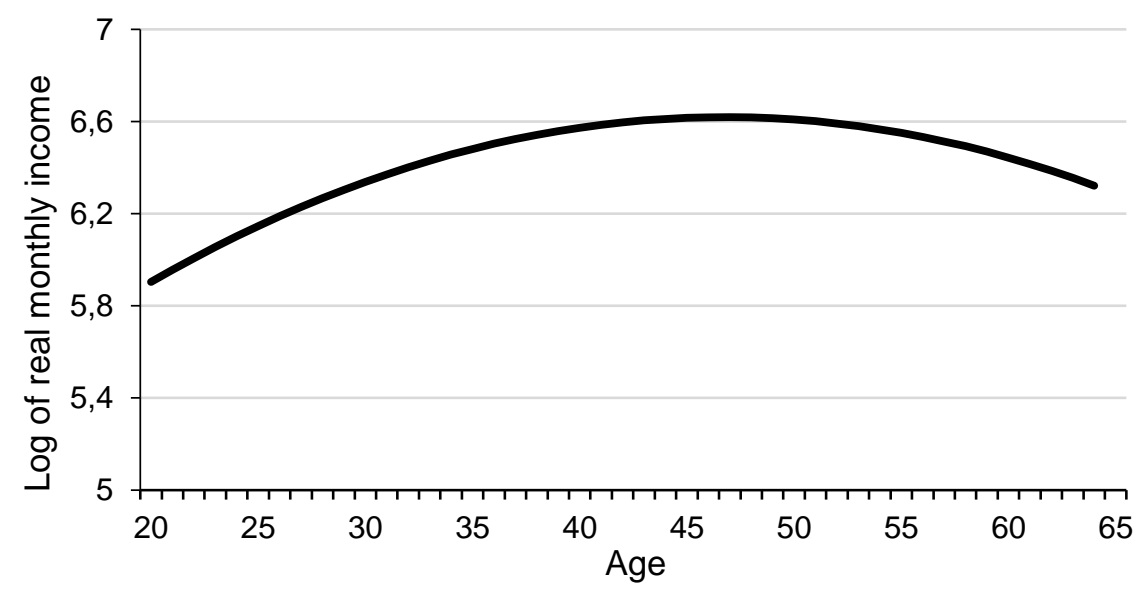

Source: authors' calculations 
In the benchmark case, parameter values for the returns of riskless and risky assets are calibrated based on historical data. The constant real long-term rate of riskless asset is set at $1.5 \%$ and the standard deviation of innovations to riskless asset return at $1 \%$ (i.e. $r=0.015$ and $\left.\sigma_{v}=0.01\right)$. Furthermore, the standard deviation of innovations to risky asset return is set at $15 \%$ (i.e. $\sigma_{\eta}=0.15$ ). Due to the population ageing risk, it is assumed that in the long-term the mean risk premium $\mu$ gradually decreases from $5 \%$ to $1 \%$.

\section{Simulation results}

\subsection{Benchmark case}

Using the model and benchmark parameter values presented in this paper, the authors simulated the shocks to both assets (i.e. $v$ and $\eta$ ) and shocks to labour income process (i.e. $n$ and $\varepsilon$ ) of 10000 participants. This allowed the calculation of independent labour income profiles and returns of both assets of these participants during their accumulation period and, respectively, wealth accumulated before retirement. Then it was possible to evaluate the lifecycle investment strategy for the Lithuanian second pension pillar that maximizes the total utility of these simulated participants. Figure 2 shows the mean results of these simulations in the benchmark case.

\section{Figure 2. Optimal participant's equity allocation for the benchmark case}

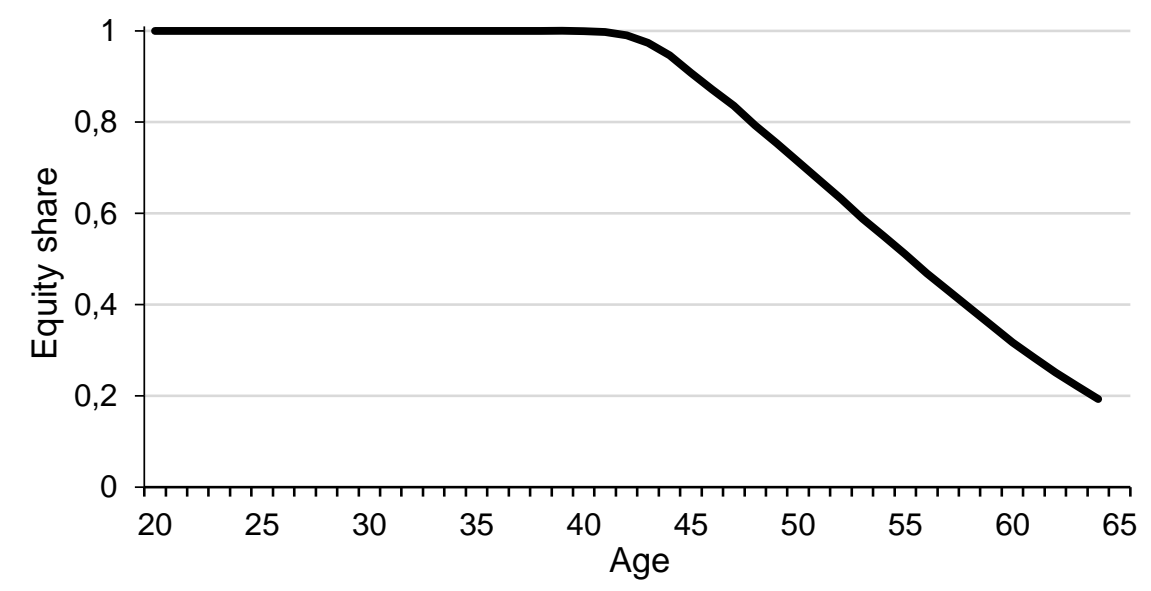

Source: authors' calculations

According to these results, the optimal life-cycle investment strategy in the Lithuanian second pension pillar confirms the conventional financial advice, which suggests for persons to switch from risky to riskless assets as they age. As it was mentioned before, these results are prepared taking into account the specifics of the Lithuanian market, where participants cannot change their contribution rate each year.

Figure 2 shows, that at the beginning of the accumulation period, when a participant is 20 years old, it is most rational to invest all his pension assets in an individual account into equities. This asset allocation should be maintained each year till the participant reaches approximately the age of 42. Such investment for a young participant allows to accumulate sufficient assets in the second pillar pension funds due to the potentially higher investment return in the equity market, when high investment risk at this young age is the mostly tolerated. After reaching approximately the age of 42 , the participant's pension asset allocation starts to gradually reduce the share of portfolio invested into equities and, respectively, increase the share of riskless assets (e.g. government bonds) as the retirement age approaches. At the last year before retirement, when 
the participant is 64 years old, it is most rational to invest only $19.3 \%$ of his pension assets in an individual account into equities. This asset allocation for senior participants should minimise the risk to lose a part of their accumulated wealth due to potential significant equity market fluctuations at the end the of the accumulation period (before the start of retirement).

This optimal asset allocation profile for equities at each year before retirement is significantly related to a participant's labour income process. A participant starts to gradually shift the share of his portfolio from equities to less risky asset, when he is approximately 42 year old. At this moment, his career income profile almost reaches a peak over working life, when growth rate of monthly real income due to age is less than $1 \%$ per year (see Figure 1).

\subsection{Sensitivity analysis}

In order to evaluate the sensitivity of optimal life-cycle investment strategy in the Lithuanian second pension pillar, the authors performed the analysis by modifying the benchmark case with different dimensions of the main parameter values. These parameters are related to a participant's contribution rates, preferences, labour income process and investment performance.

Firstly, the authors analysed how the optimal investment strategy is sensitive to various constant contribution rates, applied to the entire accumulation period (45 years). The results are presented in Figure 3.

\section{Figure 3. Optimal participant's equity allocation for various contribution rates}

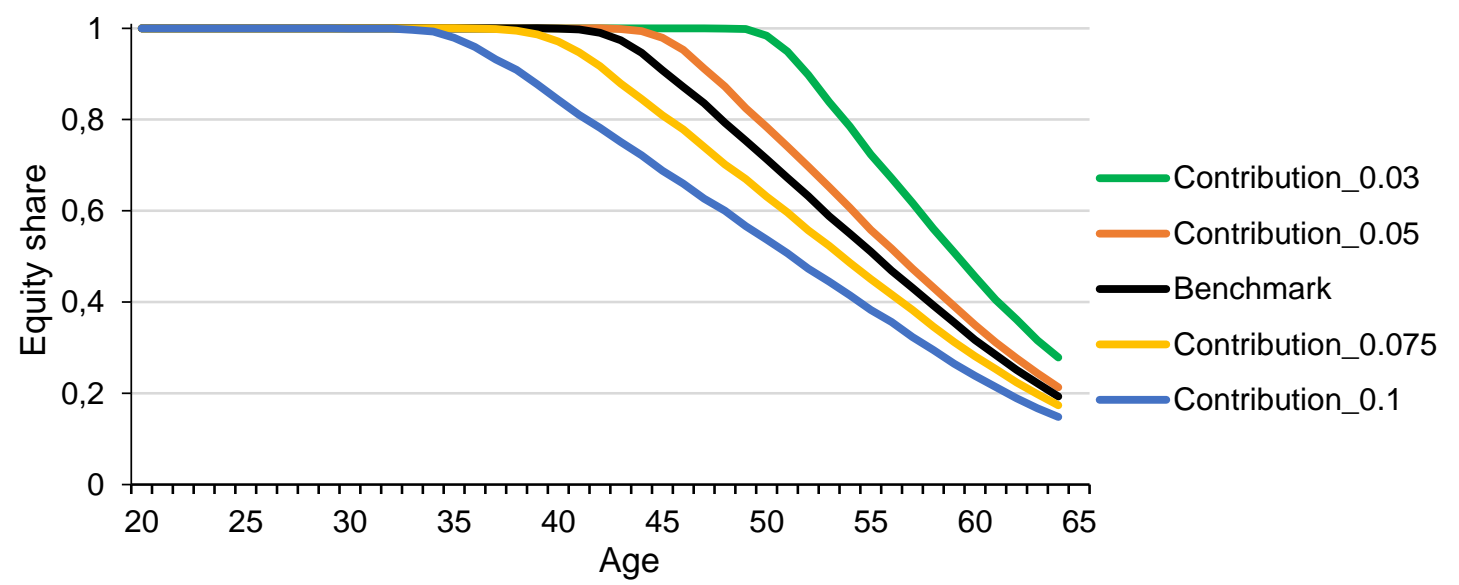

Source: authors' calculations

When contribution rate $c$ is increasing, the participant for the entirety of his working life must to pay a larger part of his labour income to the second pillar pension fund. Respectively, consumption during the accumulation period is also reduced. However, larger contributions permit the participant to accumulate higher wealth in a pension fund before retirement. Due to these reasons, a higher contribution rate during the whole accumulation period causes the participant to start reducing the share of equities in the portfolio at a younger age. When the contribution rate is lower, the optimal asset allocation operates vice versa - the reduction of the share of equities at an older age.

Secondly, the authors analysed the effects of different levels of risk aversion $\gamma$ to the optimal investment strategy. These results are shown in Figure 4.

Figure 4. Optimal participant's equity allocation for different levels of risk aversion 


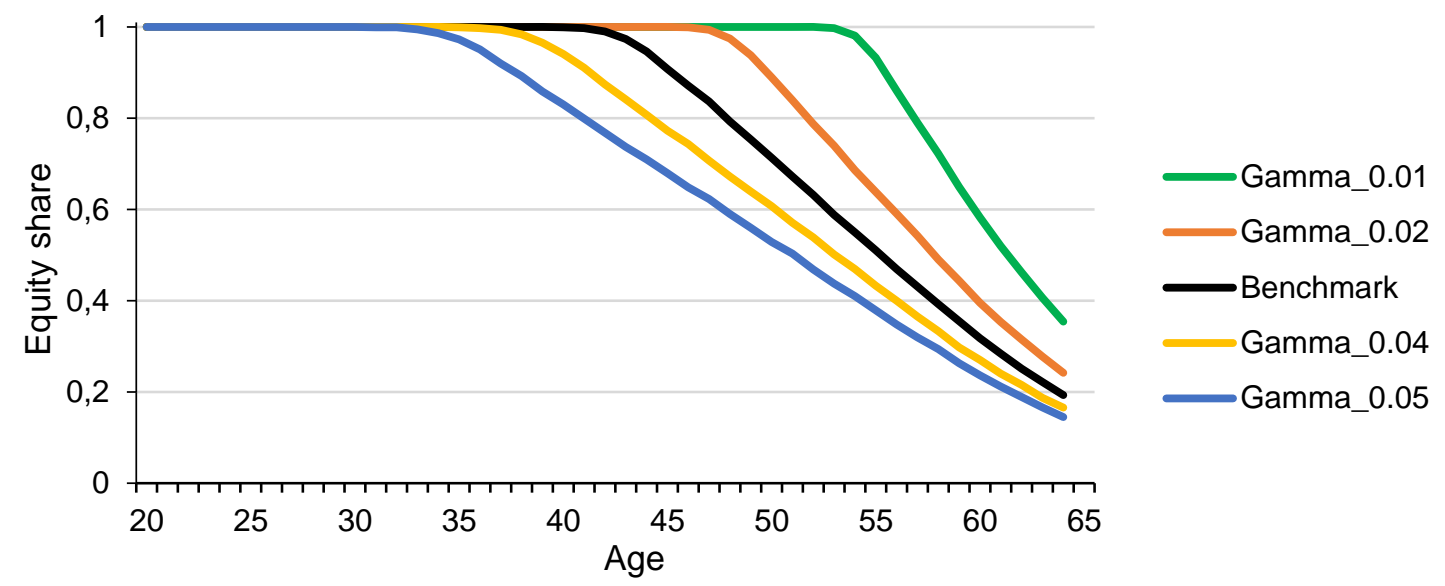

Source: authors' calculations

A participant with higher degree of risk aversion is less tolerant to uncertainty, which in this paper could be related to the accumulated wealth before retirement. Thus a higher degree of risk aversion reduces the optimal share of equities and increases the share of less risky assets in a portfolio at a younger age. This allows having a larger part of a participant's pension wealth invested into less risky assets, which serve as buffer savings in case of a depreciation in the equity market. Respectively, a participant with a lower risk aversion acts vice versa and accumulates with higher equity allocation in portfolio at all ages.

Thirdly, the analysis confirmed (see Figure 5 ) that benchmark results show low sensitivity to different degrees of correlation between shocks to equity return and labour income $(\rho)$.

Figure 5. Optimal participant's equity allocation for different degrees of correlation between shocks to equity return and labour income

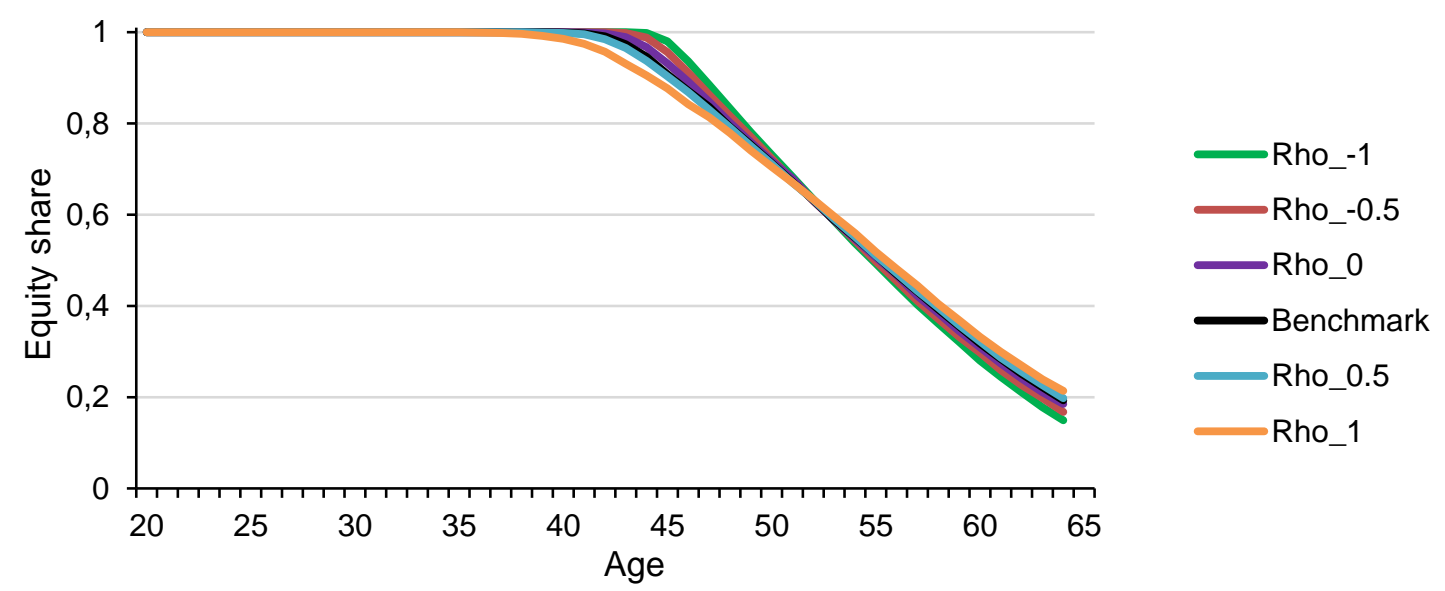

Source: authors' calculations

When correlation between these two variables increases, the optimal equity allocation starts to gradually decrease at a younger age. However, the authors assume that these changes are not very significant.

Fourthly, the authors analysed how optimal equity allocation depends on different values of mean long-term return of riskless asset $(r)$. The results are presented in Figure 6.

Figure 6. Optimal participant's equity allocation for different values of long-term return of riskless asset 


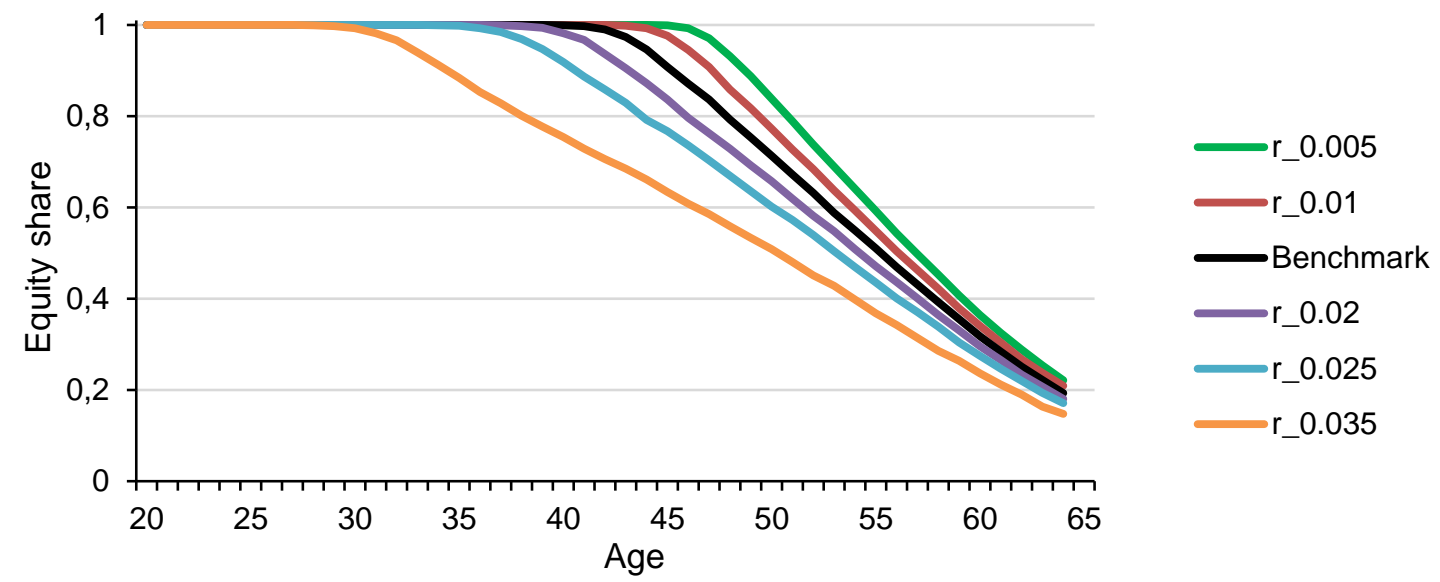

Source: authors' calculations

Results confirm that higher mean long-term return of riskless assets increase the share of this type of assets in the participant's portfolio. Due to this reason, the optimal equity allocation is lower than in the benchmark case. However, despite different values of $r$, at the last year before retirement it is optimal to invest approximately $20 \%$ of pension fund assets into equities.

Fifthly, the effects of different standard deviations of innovations to return of riskless and risky (equities) assets were analysed. The results are shown in Figures 7 and 8.

Figure 7. Optimal participant's equity allocation for different standard deviations of innovations to return of riskless asset

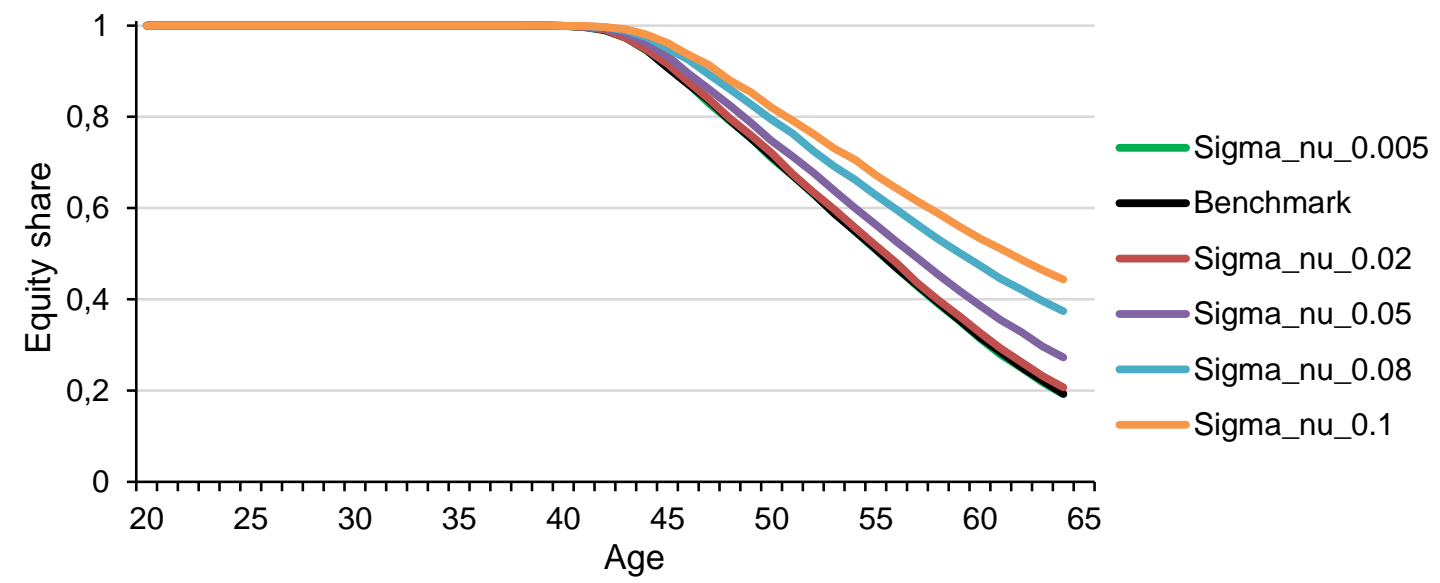

Source: authors' calculations

As it can be seen from Figure 7, the increasing standard deviation of innovations to return of riskless asset $\left(\sigma_{v}\right)$ increase the optimal share of equities in the participant's portfolio. Because this standard deviation is higher, the return of riskless asset is more volatile. This leads to a lower demand of this asset during all accumulation period. However, if $\sigma_{v}$ does not exceed value of 0.02 (or $2 \%$ ), the optimal investment strategy stays very close to the benchmark case.

Similarly, a higher standard deviation of innovations to return of equities $\left(\sigma_{\eta}\right)$ reduces the demand of this asset during all accumulation period, because the investment risk is higher. Due to this, as $\sigma_{\eta}$ increases it is optimal for the participant to invest less into equities (see Figure 8).

Figure 8. Optimal participant's equity allocation for different standard deviations of innovations to return of equities 


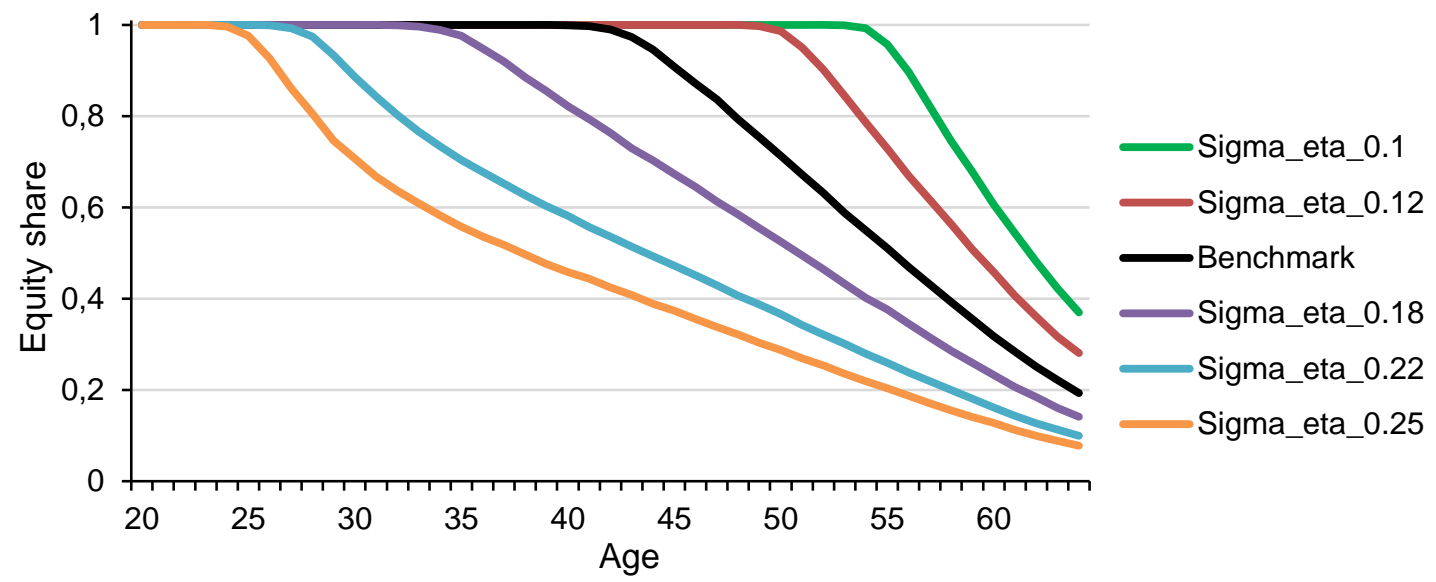

Source: authors' calculations

Lastly, the authors analysed the impact of different utility functions to the main results. As it was mentioned before, a power utility function (CRRA) with a coefficient of relative risk aversion was used in the analysed papers. However, in this case, where a participant's utility is measured only for one period (before retirement, at age 64), authors used a simpler, exponential utility function (CARA) for these calculations, which is also one of most common utility functions. In addition, the use of this function significantly reduced the time of all performed simulations. In Figure 9 the results using both utility functions are presented. Here the coefficient of relative risk aversion for power utility function is equal to 3 .

\section{Figure 9. Optimal participant's equity allocation for different utility functions}

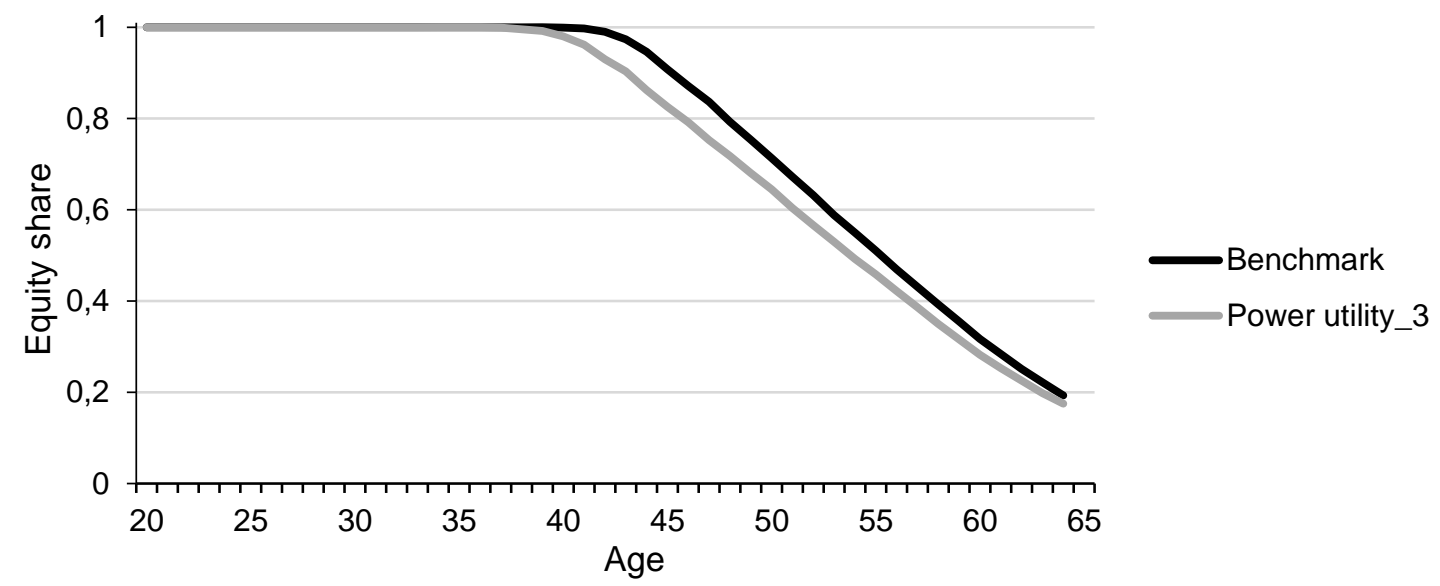

Source: authors' calculations

Figure 9 shows that in both cases it is most rational to invest less than $20 \%$ of a participant's pension assets into equities in the last year before retirement. However, simulations using the power utility function suggest starting reducing the share of equities in the portfolio 3 years earlier compared to the benchmark case.

\section{Conclusions}

In this paper, the authors prepared a model that closely follows such works as Cocco et al. (2005), Bagliano et al. (2009) and Blake et al. (2008). Due to the specifics of the Lithuanian market, where participants are not allowed to select their contribution rate (and respectively, consumption) for each period of accumulation, a modified optimization problem was used in the model. The optimal life-cycle investment strategy in the Lithuanian second pension pillar was evaluated in such a way that it would maximize the total utility of simulated participants before 
retirement. The case when the pension accumulation company does not continue to invest a person's assets after beginning of his retirement is considered. Parameters concerning the participant's labour income process were calibrated using a full deflated and depersonalised database, provided by State Social Insurance Fund Board (Sodra). Moreover, other parameters, which define investment possibilities in Lithuania, were calibrated using historical data of the investment performance of pension funds. All used parameter values are expressed in real terms, thus inflation does not have an influence on the main results of the model.

The main results of the performed simulations show that from the beginning of the accumulation period (the age of 20) till the age of approximately 42 years it is most rational to invest all pension assets of a participant's individual account into equities. Then optimal asset allocation is gradually switching from equities to less risky assets (government bonds) as the retirement age (65) approaches, where only 19 per cent of assets remain invested into equities. Additionally, hypothesis, that life-cycle investment strategy would be rational choice for second pillar pension fund's participant, was confirmed.

The authors also analysed how the optimal investment strategy is sensitive to variations of the values of the main parameters. The results show that the optimal share of equities in a participant's portfolio during the accumulation period is reduced by increasing values of contribution rate, risk aversion, long-term return of riskless asset and the standard deviation of the innovations to the return of equities. Also, optimal equity allocation is reduced by a decreasing standard deviation of innovations to return of riskless asset.

Further research could be carried out in the direction of the investment period. The simulations can be performed in the case when the pension fund continues to invest a participant's pension wealth in an individual account into the same two types of assets after the beginning of his retirement. Also, in further research, the model could be extended by introducing the separate simulation process of the state contribution of average country wage to an individual's pension account.

\section{References}

ANTOLIN, P.; PAYET, S.; YERMO, J. (2010). Assessing Default Investment Strategies in Defined Contribution Pension Plans. OECD Journal: Financial Market Trends, Vol. 2010/1, No. 5, 87-115. https://doi.org/10.1787/fmt-2010-5km7k9tp4bhb

AZOULAY, Y.; KUDRYAVTSEV, A.; SHAHRABANI, S. (2016). Accumulating Approach to the Life-cycle Pension Model: Practical Advantages. Financial theory and practice, Vol. 40, No. 4, 413-436.

BABCOCK, B. A.; CHOI, E. K.; FEINERMAN, E. (1993). Risk and Probability Premiums for CARA Utility Functions. Journal of Agricultural and Resource Economics, Vol. 18, No. 1, 17-24.

BAGLIANO, F. C.; FUGAZZA, C.; NICODANO, G. (2009). Pension Funds, Life-Cycle Asset Allocation and Performance Evaluation. Dipartimento di Scienze Economiche e Finanziarie "G. Prato”, Università di Torino, and CeRP (Collegio Carlo Alberto), Torino, March 2009.

BAGLIANO, F. C.; FUGAZZA, C.; NICODANO, G. (2017). A Life-Cycle Model with Unemployment Traps. Dipartimento di Scienze Economico-Sociali e Matematico-Statistiche, Università di Torino, and CeRP (Collegio Carlo Alberto), Torino, September 2017.

BANK OF LITHUANIA (2013). 'Il pakopos pensiju sistemos įtaka valstybès finansams ir gyventoju pajamoms ilguoju ir trumpuoju laikotarpiu.'

https://www.lb.lt/uploads/documents/files/news/pensiju sistemos modeliavimas $201303 \quad 301 . p$ df.pdf

BANK OF LITHUANIA (2016). 'Lietuvos II ir III pakopos pensijų fondų bei KIS rinkos apžvalga'. 
https://www.lb.It/lt/leidiniai/lietuvos-ii-ir-iii-pakopos-pensiju-fondu-bei-kis-rinkos-apzvalga-2016-m

BANK OF LITHUANIA (2017). 'Pensijụ sistema Lietuvoje: iššūkiai ir galimos politikos priemonès'. https://www.Ib.It/leidiniai/pensiju-sistema-lietuvoje-issukiai-ir-galimos-politikos-priemones

BYRD, R. H.; LU, P.; NOCEDAL, J.; ZHU, C. (1994). A Limited Memory Algorithm for Bound Constrained Optimization. SIAM Journal on Scientific Computing, Vol. 16, 1190-1208. https://doi.org/10.1137/0916069

BLAKE, D.; WRIGHT, D.; ZHANG, Y. (2008). Optimal Funding and Investment Strategies in Defined Contribution Pension Plans under Epstein-Zin Utility. Discussion paper PI-0808, 2008, The pensions Institute, Cass Business School, City University.

BODIE, Z.; MERTON, R. C.; SAMUELSON, W. (1992). Labour Supply Flexibility and Portfolio Choice in a Life-Cycle Model. Journal of Economic Dynamics and Control, Vol. 16 (July, 1992), 427-449. https://doi.org/10.1016/0165-1889(92)90044-F

CARROLL, C. D.; SAMWICK, A. A. (1997). The Nature of Precautionary Wealth. Journal of Monetary Economics, Vol. 40, No. 1 (March, 1997), 41-71. https://doi.org/10.1016/S0304-3932(97)00036-6

COCCO, J. F.; GOMES, F. J.; MAENHOUT, P. J. (2005). Consumption and Portfolio Choice over the Life Cycle. The Review of Financial Studies, Vol. 18, No. 2 (July, 2005), 491-533. https://doi.org/10.1093/rfs/hhi017

ÉGERT, B. (2012). The Impact of Changes in Second Pension Pillars on Public Finances in Central and Eastern Europe. OECD Economics Department Working Papers, No. 942, OECD Publishing.

FACHINGER, K.; MADER, W. (2007). Life Cycle Asset Allocation - A Suitable Approach for Defined Contribution Pension Plans. Central and Eastern European Pensions 2007, Allianz Global Investors, 25-30.

FERNANDEZ-VILLAVERDE, J.; KRUEGER, D. (2007). Consumption over the Life Cycle: Facts from Consumer Expenditure Survey Data. The Review of Economics and Statistics, (August 2007), Vol. 89, No. 3, 552-565. https://doi.org/10.1162/rest.89.3.552

GERBER, H. U.; PAFUMI, G. (1991). Utility Functions: From Risk Theory to Finance. North American Actuarial Journal, Vol. 2, No. 3, 74-100. https://doi.org/10.1080/10920277.1998.10595728

IBBOTSON, R. G.; MILEVSKY, M. A.; CHEN, P.; ZHU, K. X. (2007). Lifetime Financial Advice: Human Capital, Asset Allocation, and Insurance. Research Foundation Publications, (April, 2007).

JANKAUSKIENĖ, D.; MEDAISKIS, T. (2014). Pensions, health and long-term care. ASISP country Document, Lithuania 2014, European commission.

JOHNSON, T. C. (2007). Utility Functions. C2922 Economics, Heriot Watt University, Edinburgh. http://www.macs.hw.ac.uk/macshome/ams/msc actsci/utility final.pdf

KOLASA, A. (2012). Life Cycle Income and Consumption Patterns in Transition. Working Papers No. 17/2012 (83), Faculty of Economic Sciences, University of Warsaw. https://doi.org/10.2139/ssrn.2210348

MACCIONI, F. A.; GUDAITIS T. (2014). Contribution Options and Individual Returns after the Second Pillar Pension Reform in Lithuania. Transformations in Business \& Economics 13, 2 B.

MEDAISKIS, T; GUDAITIS T.; MEČKOVSKI J. (2018). Second pension pillar participants' behaviour: the Lithuanian case. Entrepreneurship and sustainability issues 6/2 (forthcoming).

MEYER, J. (2007). Representing Risk Preferences in Expected Utility Based Decision Models. Working Paper, Department of Economics, Michigan State University.

MERTON, R. C. (1969). Lifetime Portfolio Selection under Uncertainty: The Continuous-Time Case. The Review of Economics and Statistics, Vol. 51, No. 3 (Aug., 1969), 247-257. https://doi.org/10.2307/1926560 
PFAU, W. D. (2010). Lifecycle Funds and Wealth Accumulation for Retirement: Evidence for a More Conservative Asset Allocation as Retirement Approaches. Financial Services Review, Vol. 19, No. 1, forthcoming.

SAMUELSON, P. A. (1969). Lifetime Portfolio Selection by Dynamic Stochastic Programming. The Review of Economics and Statistics, Vol. 51, No. 3 (Aug., 1969), 239-246. https://doi.org/10.2307/1926559

VICEIRA, L. M. (2001). Optimal Portfolio Choice for Long-Horizon Investors with Nontradable Labor Income. The Journal of Finance, Vol. 56, No. 2 (April, 2001), 433-470. https://doi.org/10.1111/0022-1082.00333

VOLSKIS, E. (2012). 'Reforms of Baltic States Pension Systems: Challenges and Benefits.' www.ebrd.com/downloads/news/pension-system.pdf

ZHU, C.; BYRD, R. H.; LU, P.; NOCEDAL, J. (1994). L-BFGS-B - Fortran Subroutines for Large-Scale Bound Constrained Optimization. Report NAM-11, EECS Department, Northwestern University, 1994. 